トピックス (13)

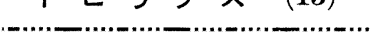

\title{
共沈法により調製した金超微粒子固定化酸化物 その微細構造と燃焼触媒およびガスセンサへの応用
}

\author{
春 田 正 毅 \\ 通産省工業技術院大阪工業技術試験所 $\bar{T} 563$ 池田市緑ケ丘 1-8-31
}

(1987 年 7 月 6 日受理)

\section{Ultrafine Gold Particles Immobilized by Coprecipitation with \\ Metal Oxides_- Their Fine Structures and Applications to Combustion Catalysts and Gas Sensors}

\author{
Masatake HARUTA \\ Government Industrial Research Institute of Osaka, AIST, MITI \\ 1-8-31 Midorigaoka, Ikeda-shi 563
}

(Received July 6, 1987)

\begin{abstract}
Gold particles smaller than $10 \mathrm{~nm}$ in diameter, immobilized with $\alpha-\mathrm{Fe}_{2} \mathrm{O}_{3}, \mathrm{Co}_{3} \mathrm{O}_{4}$, or $\mathrm{NiO}$, were prepared by calcining in air at $400^{\circ} \mathrm{C}$. The coprecipitates were obtained from an aqueous solution of $\mathrm{HAuCl}_{4}$ and the nitrate of $\mathrm{Fe}$, Co, or $\mathrm{Ni}$. The ultrafine gold particles were hemispherical in shape and were strongly held by the host oxides. In most cases, hemispherical gold crystallites were deposited directing their flat (111) plane toward $\alpha-\mathrm{Fe}_{2} \mathrm{O}_{3}$ (110), $\mathrm{Co}_{3} \mathrm{O}_{4}$ (111), and $\mathrm{NiO}$ (111). The gold particles with a mean diameter of $4.1 \mathrm{~nm}$ immobilized on $\alpha-\mathrm{Fe}_{2} \mathrm{O}_{3}$ were more electron deficient than evaporated gold particles of the same size, and much more than the bulk metal. The ultrafine gold particles thus immobilized with $3 \mathrm{~d}$ transition metal oxides were extremely active for the oxidation of $\mathrm{CO}$ at temperatures below $0^{\circ} \mathrm{C}$ and appreciably selective for $\mathrm{CO}$ sensing.
\end{abstract}

\section{1.はじめに}

金は貴金属の中でも特に安足な金属で，触媒としての 活性にそしいとされてきた。実際, 工業的に利用されて いるのは, エチレンと酰酸の酸化による酢酸ビニルの製 造に用いら机る Pd との合金だけである。金の触媒作用 については総説にまとめられているが1ー4), 特記すべき あのとしては 1 -ペンテンの $n$-ペンテンへの水素化 ${ }^{1}$ と 最近ガスクロの検出器に応用されつつあるアルコール, アルデヒド類の $\mathrm{NO}_{2}$ による部分酸化 ${ }^{5.5)}$ における高い選 択性程度であろう。

このように金が触媒として活性に乏しいとされてきた のは, 金の d 電子が完全に満たされておりイオン化エネ ルギが非常に大きい $\left(890 \mathrm{kJmol}^{-1}\right)$ という本質的特性に
加え, Pd や Pt のように高分散化するととが難しかっ たという技術的側面に由来する。金は融点が低く（1336 $\mathrm{K})$, 従って Tamman 温度も非常に低く (445 K), また昇 華エネルギあ非常に小さい $\left(368 \mathrm{kJmol}^{-1}\right)$ ので4), 焼成, 還元処理のとき非常に凝集しやすく超微粒子化して担体 に担持することが困難であった。

筆者は, 当初, 水素の低温燃焼触媒として金の複合酸 化物を調製するため共沈法を用いて各種の組み合わせを 検討したところ, ある種の金属酸化物では金が超微粒子 として固定化され，そのととにより従来考えられなかっ た新しい触媒特性が発現するととを見出した ${ }^{7.8)}$ 。本稿 では, 金の超微粒子を固定化した收族 $3 \mathrm{~d}$ 遷移金属酸化 物の微細構造とそれらの触媒, ガスセンサへの応用につ いて紹介する。 


\section{2. 共沈法により調製した金超微粒子固定化 酸化物の微細構造}

これまでの金触媒は $\mathrm{SiO}_{2}{ }^{5,9-14)}, \mathrm{Al}_{2} \mathrm{O}_{3}{ }^{11-13,15)}$, $\mathrm{MgO}^{4,12-14,16 !}, \mathrm{TiO}_{2}{ }^{17)}$ のような不活性:金属阵化物に塩 化金酸 $\left(\mathrm{HAuCl}_{4}\right)$ の水溶液を含没させて調製されてい た。この場合，金は焼成，還元の段階で凝集しやすいの で, 担持量を $2 \mathrm{wt} \%$, 好理温度を $200^{\circ} \mathrm{C}$ 以下に抑えて も, 一部の例外老除いて ${ }^{4)}$, その粒径が $10 \mathrm{~nm}$ 以上にな るのは避けられなかった。一方, 塩化金酸と金属硝酸塩 の水溶液を炭酸ナトリウム水溶液に添加して得られる共 沈物を水洗, 乾燥後, 空父中で䡒成すると, 燒成温度を $400^{\circ} \mathrm{C}$ にしても粒径 $10 \mathrm{~nm}$ 以下の金超微粒子を金属酸 化物に固定化するとよができる。

そのうち, 触媒として活性の高い屯のは $\mathrm{Au} / \alpha-\mathrm{Fe}_{2} \mathrm{O}_{3}$, $\mathrm{Au} / \mathrm{Co}_{3} \mathrm{O}_{4}$, と $\mathrm{Au} / \mathrm{NiO}$ である。相手の金属酸化物が, 見在のところ䜣族 $3 \mathrm{~d}$ 遷移金属の酸化物に限定されてい るのは共沈条件に係わる制約なのか，組み合わせそのも のに何か因果関係があるのかは不明である。触媒活性が 極大になるのは, $\mathrm{Au} / \alpha-\mathrm{Fe}_{2} \mathrm{O}_{3}\left\llcorner\mathrm{Au} / \mathrm{Co}_{3} \mathrm{O}_{4}\right.$ の場合全金 属中の金の原子\%が $5 \mathrm{~atm} \%$ のときで, $\mathrm{Au} / \mathrm{NiO}$ の場 会は $10 \mathrm{~atm} \%$ のさである

高分解能電子顕微鏡を使って共沈法， $400^{\circ} \mathrm{C}$ 焼成で調

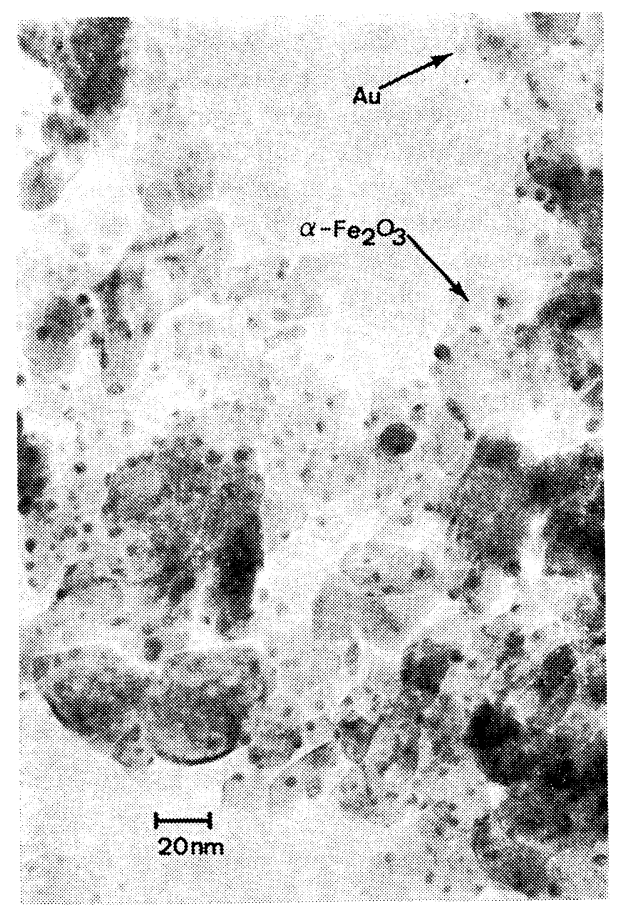

Fig. 1 Fine structure of $\mathrm{Au} / \alpha-\mathrm{Fe}_{2} \mathrm{O}_{3}(\mathrm{Au} / \mathrm{Fe}=1 /$ 19) prepared by calcining the coprecipitate at $400^{\circ} \mathrm{C}$.

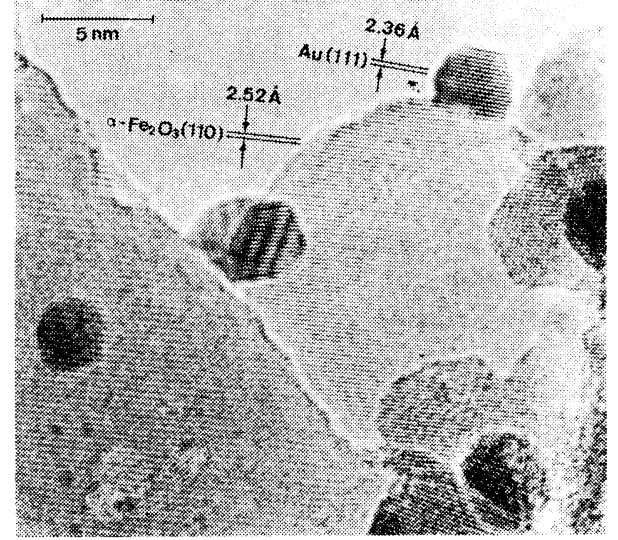

Fig. 2 Ultrafine gold particles immobilized with $\mathrm{Ti}$ doped hematite showing the lattice fringes of $\mathrm{Au}$ (111) and $\alpha-\mathrm{Fe}_{2} \mathrm{O}_{3}$ (110).

製した上記の金系触媒の微細構造老観祭した結果は以下 のようであった ${ }^{19)}$ 。

\section{$2.1 \mathrm{Au} / \alpha-\mathrm{Fe}_{2} \mathrm{O}_{3}$ の微細構造}

Fig. 1 に示すように, 金の超微粒子が $\alpha-\mathrm{Fe}_{2} \mathrm{O}_{3}$ 粒子 表面上に均一に担持されており，その平均料子径（算出 個数：2131)は $4.1 \mathrm{~nm}$, 棐準偏差は $1.4 \mathrm{~nm}$ である。金 超微精子は明視野, 暗視野での観然から双晶や多晶でな く単結昆であるこよがわかっている。酸化鉄はX線回折 及び電子線回折から $\alpha-\mathrm{Fe}_{2} \mathrm{O}_{3}$ であることが確認されて いるが，20〜30 nm のほ球状の粒子及びそれらが凝 集・燒結してできた $50 \mathrm{~nm}$ 前後の不是形粒子から成っ ている。

金超微粒子とへマタイト敉子との接合界面付近をさら に拡大して観察すると (Fig. 2), 金超微䊀子は球状でな く半球状で，その半らな底面の部分で接合して招り，へ マタイトの（110）面に刘し $\mathrm{Au}(111)$ 面加挨合した特定

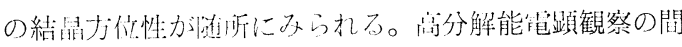

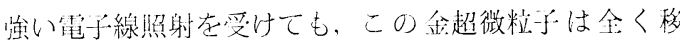
動, 凝集せず, シリカや谈尖の表面に真空蒸着した梂状 に近い 1.5〜 $5 \mathrm{~nm}$ の金超微粒-ヂアミーバのように動 き凝集するとの飯島らの報告 ${ }^{20,21)}$ と対照的である。共沈 法で調製したものでは，還元，胵化処理をして担体を $\alpha-\mathrm{Fe}_{2} \mathrm{O}_{3} \rightarrow \mathrm{Fe}_{3} \mathrm{O}_{4} \rightarrow \gamma-\mathrm{Fe}_{2} \mathrm{O}_{3}$ と変化させても, 金超微粒 子と酸化鉄との接合界泊は強固に凮定されており金超微 椟子の精径が全く変化しないことから ${ }^{22)}$, 画者の間で強 い相互作用があることがわかっている。

\section{$2.2 \mathrm{Au} / \mathrm{Co}_{3} \mathrm{O}_{4}$ の微細構造}

粒子径 6 7 nm の金超微粒子が $20 \mathrm{~nm}$ 前後の $\mathrm{Co}_{3} \mathrm{O}_{4}$ 粒于に分散されているが, $\mathrm{Au} / \alpha-\mathrm{Fe}_{2} \mathrm{O}_{3}$ の場合程高分散 されていない (Fig. 3)。これは, 担体である $\mathrm{Co}_{3} \mathrm{O}_{4}$ の 


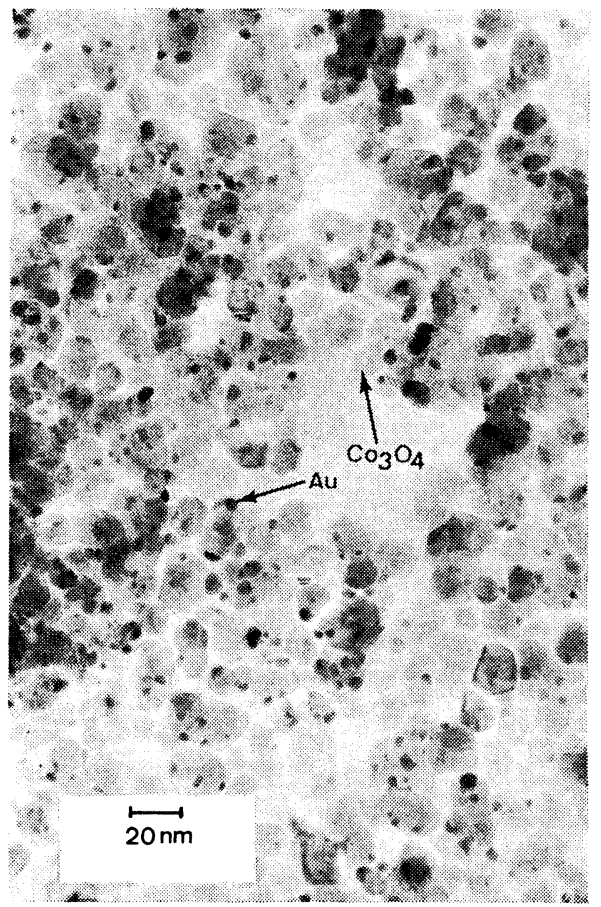

Fig. 3 Fine structure of $\mathrm{Au} / \mathrm{Co}_{3} \mathrm{O}_{4}(\mathrm{Au} / \mathrm{Co}=1 /$ 19) prepared by calcining the coprecipitate at $400^{\circ} \mathrm{C}$.

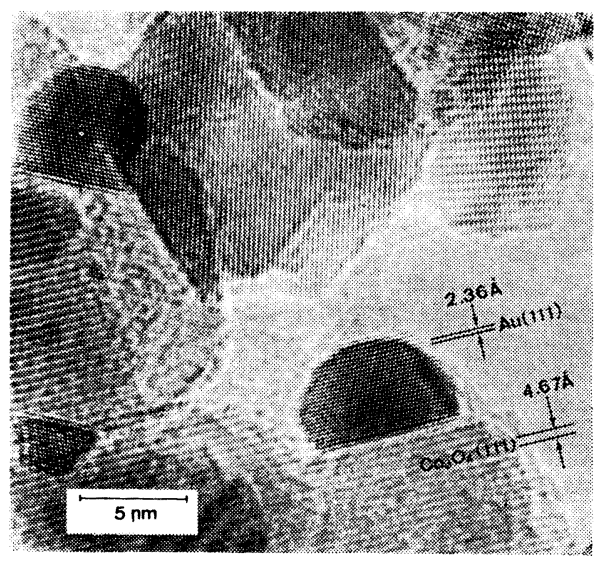

Fig. 4. Ultrafine gold [ particles immobilized with $\mathrm{Co}_{3} \mathrm{O}_{4}$ showing the lattice fringes of $\mathrm{Au}$ [111] and $\mathrm{Co}_{3} \mathrm{O}_{4}$ [111].

沈でん前駆体 $\left(\mathrm{CoCO}_{3}\right)$ 粒子が小さく, 烧成中に析出し てくる金が安定に按合される $\mathrm{Co}_{3} \mathrm{O}_{4}$ の絬晶面を見出せ ず凝集が起こりやすくなったためと考えられる。Fig.4 に示すように，酸化コバルト粒子 1 個に対して概ね金超 微粒子 1 個が接合された状態となっており，乙の場合は $\mathrm{Co}_{3} \mathrm{O}_{4}$ の (111) 結晶面に刘し金の (111) 面が方位して 成長しているところが多く岇ら机る。

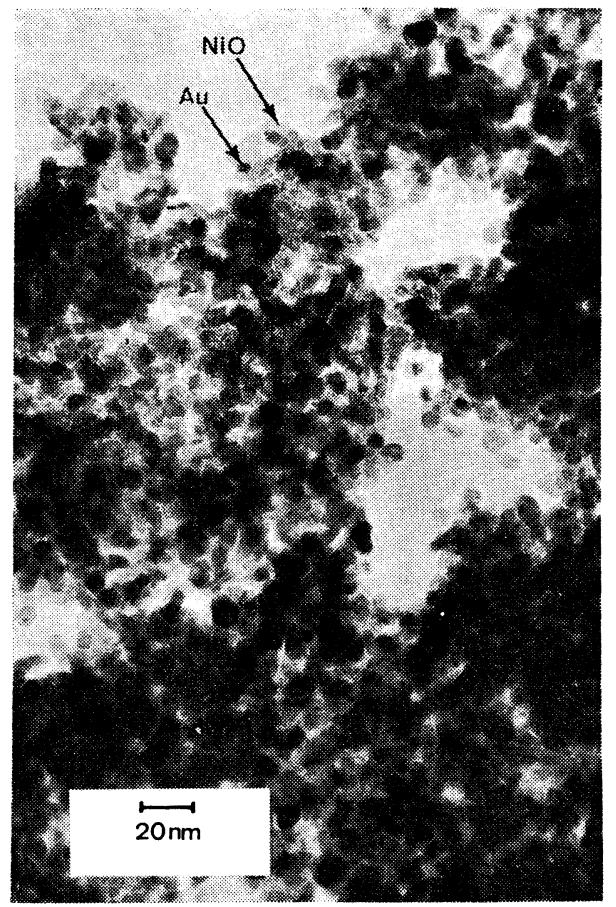

Fig. 5 Fine structure of $\mathrm{Au} / \mathrm{NiO}(\mathrm{Au} / \mathrm{Ni}=1 / 9)$ prepared by calcining the coprecipitate at $400^{\circ} \mathrm{C}$.

\section{$2.3 \mathrm{Au} / \mathrm{NiO}$ の微細構造}

ニッケル金属イオンは水溶液で沈でんさせると，北労 に微細な粒子となり沈降しにくいので洗浄が困難であ 万。乙の性質を反映して, Fig. 5 に示すように, 酸化二 ッケルが約 $10 \mathrm{~nm}$ の非常に微細な粒子となっており，金 超微粘子の粒徍との差が小さい。金超微粒子は担挴され ているというより，むしろ混合された状態にあり，7〜8 $\mathrm{nm}$ 程度である。この場命屯，Fig. 6 亿示すように， $\mathrm{NiO}$ の (111) 絬鼠面に対し $\mathrm{Au}$ が (111) 面を方位して 成交している所が多くみられた。 $\mathrm{Au} / \mathrm{NiO}$ 系の場合は, $\mathrm{Au}$ 含最が $5 \mathrm{~atm} \%$ より $10 \mathrm{~atm} \%$ の方が酸化触媒活恻: が高い。乙れは $\mathrm{NiO}$ 䊀子が非常に小さいので， $\mathrm{Au}$ が $\mathrm{NiO}$ 粒子表面上に担持されにくく凝集を受けやすいた めそれだけ多量の $\mathrm{Au}$ が必要とされるからであろう。

\section{4 共沈法金超微粒子固定化酸化物 の特徵と含浸法} 担持金触媒との微細構造の違い

其沈法で周製した $\mathrm{Au} / \alpha-\mathrm{Fe}_{2} \mathrm{O}_{3}, \mathrm{Au} / \mathrm{Co}_{3} \mathrm{O}_{4}, \mathrm{Au} / \mathrm{NiO}$ においては，水酸化物あるいは炭酸塩の共沈物を焼成す る段階で, $\alpha-\mathrm{Fe}_{2} \mathrm{O}_{3}$ 等の酸化物の生成と結晶化が進むと 同時に金は酸化物が不安定で還元され母体の金属酸化物 の内部から表面へ出てきて析出する。このため，金超微

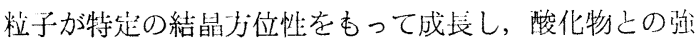




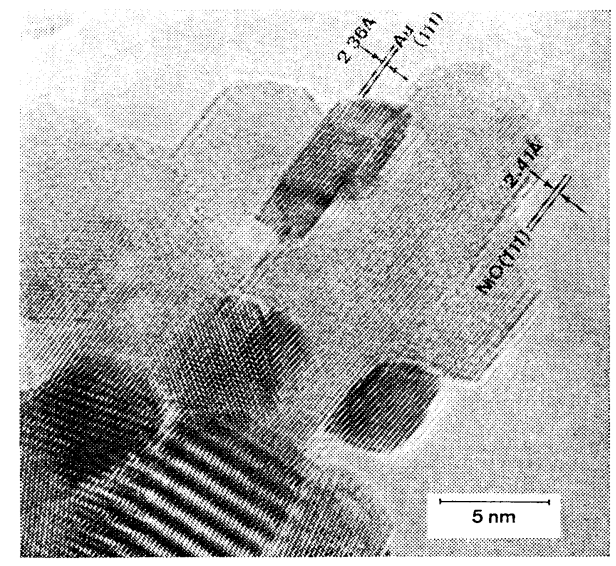

Fig. 6 Ultrafine gold particles immobilized with $\mathrm{NiO}$ showing the lattice fringes of $\mathrm{Au}$ (111) and $\mathrm{NiO}(111)$.

い相互作用が出現すると考えられる。金超微粒子の粒径 は，相手の酸化物粒子が小さくなる程 $\left(\alpha-\mathrm{Fe}_{2} \mathrm{O}_{3}>\mathrm{Co}_{3} \mathrm{O}_{4}\right.$ $>\mathrm{NiO})$, 增大する傾向がある。

一方, 予め調製しておいた $\alpha-\mathrm{Fe}_{2} \mathrm{O}_{3}$ 粉末に $\mathrm{HAuCl}_{4}$ 水溶液を含浸させた場合は, $90^{\circ} \mathrm{C}$ のような低温で水菜還 元しても, Fig. 7 に示すように金微粒子は直径 $10 \mathrm{~nm}$ 以上となり，ヘマタイト粒子間にまばらに分散した状態 であった。金微粒子はほぼ球状で, 金微粒子とへマタイ トとの相互作用が弱いため, 還元処理温度を上げると凝

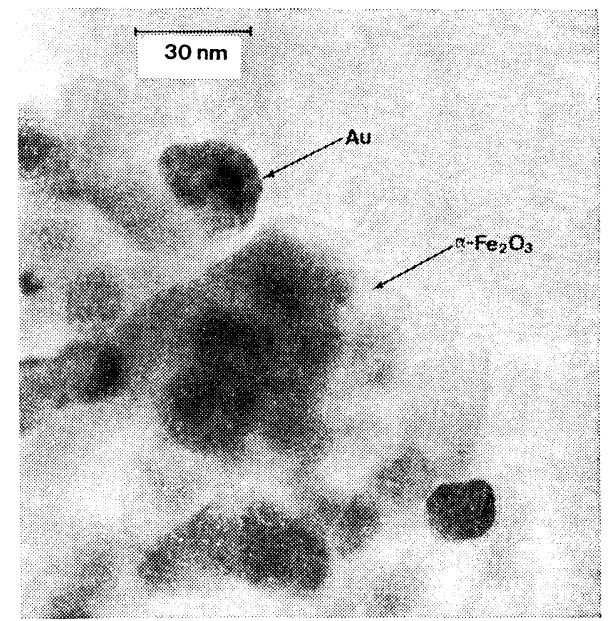

Fig. 7 Fine structure of gold supported on hematite by impregnation and $\mathrm{H}_{2}$ reduction at $90^{\circ} \mathrm{C}$.

集が進み, CO 酸化触媒活性が著しく低下する。

\section{5 金超微粒子の電子状態}

Fig. 8 は, 種々の温度で焼成した試料の $\mathrm{Au}_{4} \mathrm{f}_{5 / 2+7 / 2}$, $\mathrm{Au} 4 \mathrm{~d}_{5 / 2}$ 及び $\mathrm{O} 1 \mathrm{~s}$ スペクトルを示す ${ }^{22)}{ }_{0} \mathrm{Au} 4 \mathrm{f}$ 上 $4 \mathrm{~d}$ の結 合エネルギ (BE) は焼成温度が上がるにつれて，低エネ ルギ側に変化しているが，400C 烧成のあのでも金粉末 の BEよりは高い。また，ピーク巾も焼成温度の上昇に 伴い狭くなっており, このことは Au4f で2つのピーク

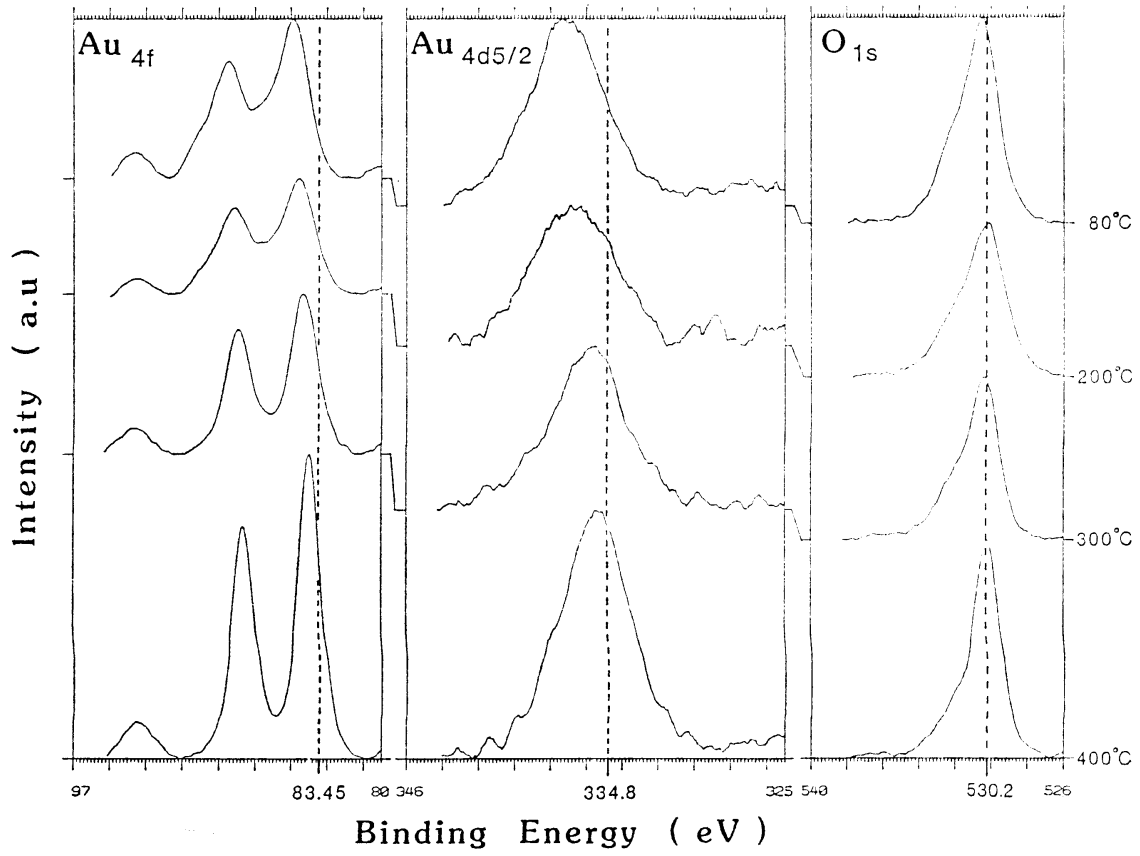

Fig. 8 Change of XPS spectra of coprecipitated gold and iron with calcination temperature. 
の間の谷が深くなっていることからあ明らかである。酸 化金 $\mathrm{Au}_{2} \mathrm{O}_{3}$ の $\mathrm{Au}_{4} 4 \mathrm{f}_{7 / 2}$ は $\mathrm{BE}$ が $86.4 \mathrm{eV}, \mathrm{Au} 4 \mathrm{f}_{5 / 2}$ は $90.0 \mathrm{eV}$ であったので, $80^{\circ} \mathrm{C}, 200^{\circ} \mathrm{C}$ 燒成試料の $\mathrm{Au} 4 \mathrm{f}$ スペクトルに見られる高エネルギ側のショルダーは $\mathrm{Au}_{2} \mathrm{O}_{3}$ が混在するととを示している。高い $\mathrm{CO}$ 酸化活 性の得られる $300^{\circ} \mathrm{C}$ と $400^{\circ} \mathrm{C}$ 焼成の試料では, $\mathrm{BE}$ が $\mathrm{Au} 4 \mathrm{f}, 4 \mathrm{~d}$ と屯約 $0.5 \mathrm{eV}$ 程高エネルギ側にシフトして いる。乙のケミカルシフトは, 蒸着した平均粓子径 6.2 $\mathrm{nm}$ の金超微粒子について報告されている值 $0.2 \mathrm{eV}^{23}$ と比べかなり大きい。

金超微粒子がてのように電子欠損になっている理由と しては, 次の 3 つの可能性が䓅えられる。

1) 単なる超微粒子効梨

2) 金超微䊀子加ら $\alpha-\mathrm{Fe}_{2} \mathrm{O}_{3} へ$ 電子移行

3）金亡鉄の合金超微粒子の生成

共沈法で調製した金超微粘子は絓晶方位性をもって非 常に強固に金属酸化物と接合していることとケミカルシ フトの值が通常の金超微粒子の場合に比べ大きいことか ら，2)，3)の現象の寄与が大きいと考えられる。

担持された金属の超微粒子が担体へ電子を供与するこ とにより電子欠損になり, 電子的に周期律表の左隣り の金属の性質に似てくることが報告されていることか $ら^{11}$ ，酸化鉄に固定された金超微粒子についても不対 $\mathrm{d}$ 電子のない状態から電子供与により白金に似た電子状態 に近づいている可能性は高い。金と鉄との合金形成の可
能性については, $300^{\circ} \mathrm{C} \sim 400^{\circ} \mathrm{C}$ の温度範国で $\mathrm{Au}$ 中に $\mathrm{Fe}$ が 11〜16 原子\%も固溶できることが報告されてい $ろ^{24)}$ 。母体酸化鉄の結晶変態を起こさせても, 金の超微 粘子の平均粒径は全く変わらず非常に強固に両者が接合 していることから，少なくとも接合界面では $\mathrm{Au} と \mathrm{Fe}$ との金属間化合物が形成されているであろう。

\section{3. 低温燃焼触媒への応用}

金超微粒子固定化酸化物は，水素や一酸化炭素などの 燃えやすいガス燃料を点火すせずに自然に室温から燃烤 できる触媒として利用できる ${ }^{25,26)}$ 。Fig. 9 に種々の触 媒上での水素之一酸化炭素の酸化反応率と温度との関係 を示す。パラジゥム, 金などの貴金属上では, 水素の酸 化の方が一酸化炭素の酸化よりはるかに起とりやすく, 反応温度が約 $200^{\circ} \mathrm{C}$ 程低い。一方，鉄，コバルト，ニッ ケルなどの卑金属の酸化物上では, 水素より一酸化炭素 の酸化の方が低い温度で起こる。金超微粒子を固定化し た $\alpha-\mathrm{Fe}_{2} \mathrm{O}_{3}, \mathrm{Co}_{3} \mathrm{O}_{4}$, 及び $\mathrm{NiO}$ は担体となるてれらの金 属酸化物之同様な触媒特性をもち, 一酸化炭素の酸化の 方がより低い温度で起てる。しかも，その温度差が 100 ${ }^{\circ} \mathrm{C}$ 以上あり, 貴金属触媒亡丁度正反対の触媒特性を示 すととは注目に值する。

Fig. 10 は共沈法と含浸法で調製した金系触媒の $\mathrm{H}_{2}$ と $\mathrm{CO}$ 亿対する酸化活性と金の粒徍との関係を示す ${ }^{8)}$ 。 含浸法や還元法では $200^{\circ} \mathrm{C}$ また $300^{\circ} \mathrm{C}$ で䡒成しても

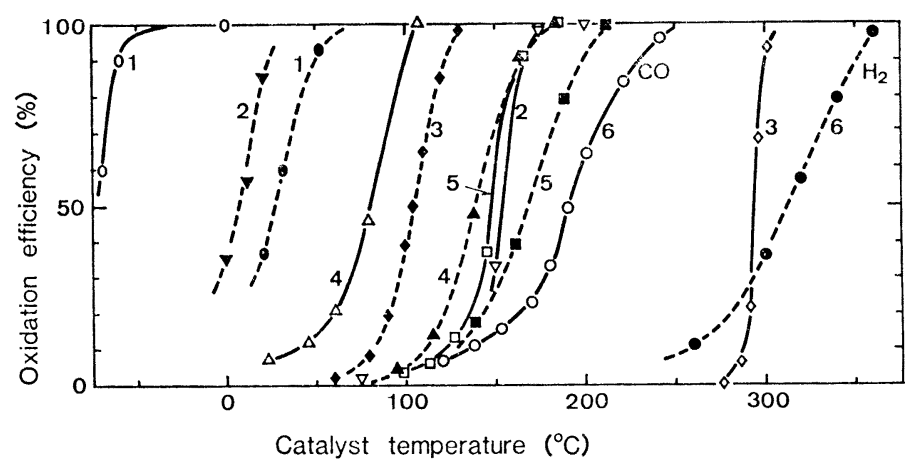

Fig. 9 Catalytic oxidation of $\mathrm{H}_{2}$ and $\mathrm{CO}$ over various metals and metal oxides.

…: $\mathrm{H}_{2}$ oxidation - : $\mathrm{CO}$ oxidation

1: $\mathrm{Au} / \alpha-\mathrm{Fe}_{2} \mathrm{O}_{3}\left(\mathrm{Au} / \mathrm{Fe}=1 / 19\right.$, coprecipitation, $\left.400^{\circ} \mathrm{C}\right)$

2: $0.5 \mathrm{wt} \% \mathrm{Pd} / \mathrm{Al}_{2} \mathrm{O}_{3}$ (impregnation, $300^{\circ} \mathrm{C}$ )

3: Au fine powder

4: $\mathrm{Co}_{3} \mathrm{O}_{4}$ (carbonate, $400^{\circ} \mathrm{C}$ )

5: $\mathrm{NiO}$ (hydrate, $400^{\circ} \mathrm{C}$ )

6: $\alpha-\mathrm{Fe}_{2} \mathrm{O}_{3}$ (hydrate, $400^{\circ} \mathrm{C}$ ),

Reaction conditions : catalysts $42-70$ meshes, $\mathrm{H}_{2}$ or $\mathrm{CO} 1 \mathrm{vol} \%$ in air, space velocity $=2 \times 10^{4} \mathrm{~h}^{-1} \mathrm{ml} / \mathrm{g}$ 


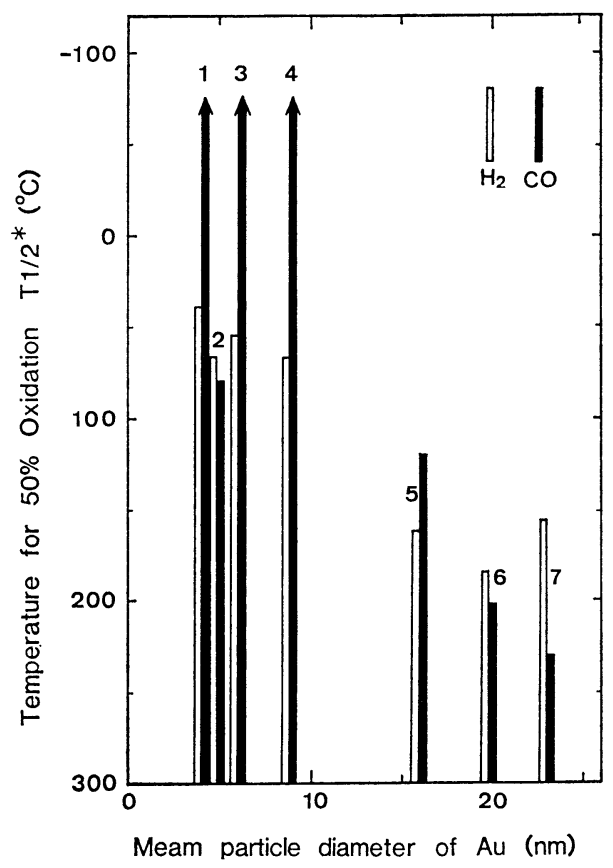

Fig. 10 Catalytic activities for $\mathrm{H}_{2}$ and $\mathrm{CO}$ oxidation as a function of mean particle diameter of Au.

1: $\mathrm{Au} / \alpha-\mathrm{Fe}_{2} \mathrm{O}_{3}(\mathrm{Au} / \mathrm{Fe}=1 / 19$, coprecipitation, $400^{\circ} \mathrm{C}$ )

2: $\mathrm{Au} / \mathrm{Al}_{2} \mathrm{O}_{3}(\mathrm{Au} / \mathrm{Al}=1 / 19$, coprecipitation, 400 $\left.{ }^{\circ} \mathrm{C}\right)$

3: $\mathrm{Au} / \mathrm{Co}_{3} \mathrm{O}_{4}(\mathrm{Au} / \mathrm{Co}=1 / 19$, coprecipitation, 400 $\left.{ }^{\circ} \mathrm{C}\right)$

4: $\mathrm{Au} / \mathrm{NiO}(\mathrm{Au} / \mathrm{Ni}=1 / 19$, coprecipitation, 400 $\left.{ }^{\circ} \mathrm{C}\right)$

5: $\mathrm{Au} / \alpha-\mathrm{Fe}_{2} \mathrm{O}_{3}$ (Au 5 wt \%, impregnation, 200 ${ }^{\circ} \mathrm{C}$ )

6: $\mathrm{Au} / \mathrm{SiO}_{2}$ (Au $17 \mathrm{wt} \%$, reduction by citrate, $\left.300^{\circ} \mathrm{C}\right)$

7: $\mathrm{Au} / \nu-\mathrm{Al}_{2} \mathrm{O}_{3}(\mathrm{Au} 5 \mathrm{wt} \%$, impregnation, 200 ${ }^{\circ} \mathrm{C}$ )

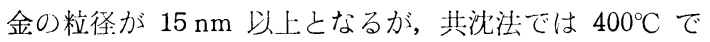
邺成して屯 $10 \mathrm{~nm}$ 以下の超微粒子となる。水素の酸化 活性は金の社径が大きくなるにつれ単調に減少し，金の 露出表面積に依存するとみることができる。一正，一糉 化获素の酸化に対しては金の粒径を制御するだけでは充 分な触媒活性は得られない。すなわち，共沈法で調製し た同じ数 $\mathrm{nm}$ の金超微粒子であっても, 組み合わせる酸 化物が $\mathrm{Al}_{2} \mathrm{O}_{3}$ のような不活性な酸化物では高い $\mathrm{CO}$ 酸 化活性は得られない。

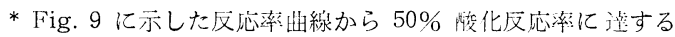
混度 $\left(T_{1 / 2}\right)$ で表わしている。
白金表面への CO 吸着熱は 26 (110 面) 38.5(100 面） $\mathrm{kcal} / \mathrm{mol}$ と非常に大きく, CO の收符が強すぎるの で酸素吸着が踈外される。そのために, Ptや $\mathrm{Pd}$ 上では $\mathrm{CO}$ の低温酸化が起こりにくい。一㝳，金表面への CO 吸着熱は $9 \mathrm{kcal} / \mathrm{mol}$ と小さく, CO 吸新が起こりにく (27)。酸化鉄に固定化された金超微粘子てでは，担体金属 酸化物との相互作用により，2.5節で述べたように， $\mathrm{CO}$ 吸着が白金のように強すぎず，かつ金のように弱す ぎないような表而状態が現われていると荐えられる。

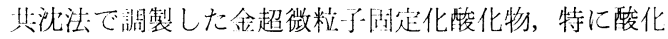
䜬との組み合わせは，湿父需用父の方がむしろ活性が高 く，客定性にも侵れており，水素や一酸化炭素の触媒燃 烛, 封入型 $\mathrm{CO}_{2}$ レーザ (分解 $\mathrm{CO}$ の再酸化), 空気清陴

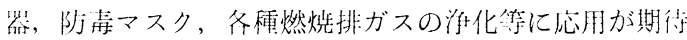
されている。

\section{4．一酸化炭素選択性ガスセンサへの応用}

金超微䊀于活定化酸化物が $\mathrm{H}_{2}$ に比べ $\mathrm{CO}$ に対して はるかに高い酸化触媒活性をもっていることに着目し て，CO 選択性ガスセンサへの応用を試みた ${ }^{28,29)}$ 。セン サ素子は，櫛形金電極を蒸着したアルミナ基板 $(10 \times 17$ $\mathrm{mm}$ ) に，少最の水を加えて微粉研して作ったペースト を塗布して, 空気中 $600^{\circ} \mathrm{C}$ で 1 時間焼成することにより 作成した。ガスセンサ材料の候補としては，感度及び安 㳬性の点から日体の金属酸化物が $\mathrm{n}$ 型半導体の方が好ま しいので, $\mathrm{Au} / \alpha-\mathrm{Fe}_{2} \mathrm{O}_{3}$ を選んだ。

酸化触媒， $\mathrm{Au} / \alpha-\mathrm{Fe}_{2} \mathrm{O}_{3}$ このあのをセンサ菜子とする 之, 素子抵抗は $250^{\circ} \mathrm{C}$ でも $10 \mathrm{M} \Omega$ 以上となり, センサ として抵抗変化を測定することが困難である。そこで, $\mathrm{n}$ 型半導性を高めるため $\alpha-\mathrm{Fe}_{2} \mathrm{O}_{3}$ に 4 価の金属イオン をドープした絬果, $\mathrm{Fe}^{3+}$ とイオン半径が最も近い $\mathrm{Ti}^{4+}$ を3 atm \%ドープすると, 電気抵抗が最も小さくなり, 2 桁程低くなることがわかった。この結果から, Au/Fe $=1 / 19, \mathrm{Ti} / \mathrm{Fe}=3 / 97$ をガスセンサ材料の組成とした。

Fig. 11 に, $\mathrm{CO}, \mathrm{H}_{2}$, エ夕ノール蒸父に刘する検知感 度とセンサ素子溫度との関係を示す。還元性ガスにより 榆知感度の極大を示す洁度が罢なっており，COでは $50^{\circ} \mathrm{C}$, エ夕ノールでは $150^{\circ} \mathrm{C}, \mathrm{H}_{2}$ では $250^{\circ} \mathrm{C}$ である。 网中，们側に永した金を含まないn 型半導性: $\alpha-\mathrm{Fe}_{2} \mathrm{O}_{3}$ $(\mathrm{Ti} / \mathrm{Fe}=3: 97)$ の場合と比較すると, 金の存在により罡 元性ガスを検知できる温度が $100^{\circ} \mathrm{C}$ 以上低温側にシフト しているが，なかであ CO に刘する效果が褧も著しい ことがわかる。

以上のように，金超微粒子在固定化した酸化鉄半導体 センサでは $50^{\circ} \mathrm{C}$ 以下にセンサ素子温度老設定すると, $\mathrm{CO}$ を選択的に検知するととができる。素子温度 $40^{\circ} \mathrm{C}$ 


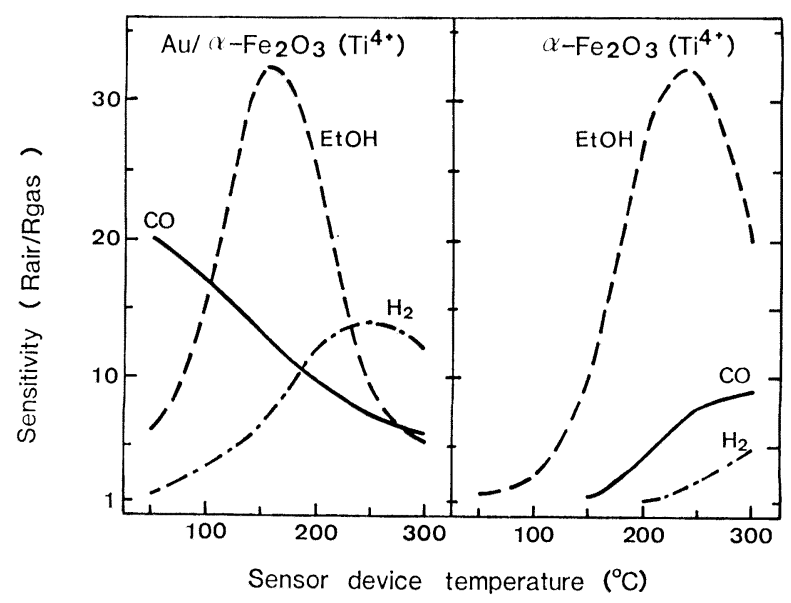

Fig. 11 Sensitivities to $\mathrm{CO}, \mathrm{H}_{2}$, and $\mathrm{EtOH}$ of $\mathrm{Ti}$ doped hematites with and without $\mathrm{Au}$ particles as a function of device temperature.

では, CO $20 \mathrm{ppm}$ の検知感度は, $1,000 \mathrm{ppm}$ のエタノ 一ル感度と同程度であり, $\mathrm{H}_{2}$ に対する感度はさらに低 い。また, CO $100 \mathrm{ppm}$ に対する応答時間（到達感度の $90 \%$ 值に達する時間) は, $40^{\circ} \mathrm{C}$ という低い作動温度で 屯約 40 秒であり, 充分速い答が得られている。

\section{5.おわりに}

超微粒子は表面に存在する原子の割合が高く，バルク とは異なった性質を示す点は学間的に興味が尽きない。 しかし，反面その表面エネルギが非常に高いため経時安 定性に欠け，奏用化への道はそれだけ困難なことが多 い。実用化の観点からは，超微粒子そのものを別個に製 造してから利用目的に合った材料形態に仕上げるより, 使用される形態で直接固定化, 安定化して製造すること が近道と思われる。古くから, Pd, Pt などの貴金属触媒 の調製はこの方法論で行われている。

本稿で紹介した金超微粒子国定化酸化物は本来超微粒 子の調製を目的にして得られたものではなかった。しか し, その特異な触媒活性の原因を追求する過程で金超微 粒子の存在を見出した結果，超微粒子と担体との相互作 用により今までにない新しい触媒特性が出現することを 知ることができた。将来的には, 気相薄膜形成技術を使 って酸化鉄等に金超微粒子を固定化した各種のモデル構 造を作成し，化学的に不活性とされてきた金から新しい 機能を引き出したいと考えている。

謝 辞 本研究の高分解能電顕写真の一部は飯甶澄 男博士 (NEC 基礎研) に, XPS は Prof. F. Delannay (ルーヴァン・カトリック大)に，ガスセンサへの応用は 小林哲彦博士 (大工試) によるあのである。ここに記し
て感謝の意を表する。

\section{文 献}

1) G. C. Bond and P. A. Sermon : Gold Bull. 6, 102 (1973).

2) I. E. Wachs : Gold Bull. 16, 98 (1983).

3) J. Schwank: Gold Bull. 16, 103 (1983).

4) G. Zhang: $\mathrm{Ph}$. D. Thesis, Stanford University, UM 8608245 (1985).

5) S. A. Nyarady and R. E. Sievers : J. Am. Chem. Soc. 107, 3726 (1985).

6) Chem. Engng. News, June 24, 1985, pp 42-44.

7) M. Haruta, T. Kobayashi, H. Sano and N. Yamada: Chem. Lett. 1987, 405 (1987).

8) 春田正毅: 化学亡工業 40 (4), 306 (1987).

9) D. J. Yates : J. Colloid. Interf. Sci. 29, 194 (1969).

10) Y. L. Lam and M. Boudart: J. Catal. 50, 530 (1977).

11) P. A. Sermon, G. C. Bond and P. B. Wells : J. Chem. Soc. Faraday I 74, 385 (1978).

12) S. Galvagno and G. Parravano: J. Catal. 55, 178 (1978).

13) T. Fukushima, S. Galvagno and G. Parravano: J. Catal. 57, 177 (19.9).

14) J. Y. Lea and J. Schwank: J. Catal. 102, 207 (1986).

15) D. A. Buchanan and G. Webb: J. Chem. Soc. Faraday I 70, 134 (1974).

16) J. Schwank, G. Parravano and H. L. Gruber : J. Catal. 61, 19 (1980).

17) A. G Shastri, A. K. Datye and J. Schwank: J. Catal. 87, 265 (1984).

18）春田正毅, 佐野 寛: 触媒 26, 140 (1984).

19）春田正毅, 飯島澄男, 山田延正, 小林哲彦: 第 58 回触媒討論会 (A) 講演予稿集, 108 (1986). 
20) S. Iijima and T. Ichihashi : Jap. J. Appl. Phys. 24, L 125 (1986).

21) S. Iijima and T. Ichihashi : Phys. Rev. Lett. 56, 616 (1986).

22) 春田正毅, F. Delannay, 飯島澄男, 小林哲彦: 触 媒 29(2), 162 (1987).

23) L. Oberli, R. Monat, H. J. Matieu, D. Landolt and J. Butter: Surf. Sci. 106, 301 (1981).

24) E. Raub and P. Walter : Z. Metallkunde 41, 234
(1979).

25）春田正毅：触媒 $29(4), 299$ (1987).

26）春田正媇：ソーダと塩素 38(4)，133 (1987).

27）松島龍夫: 表面 23, 259 (1985).

28）小林哲彦，春田正毅： センサ技術 7(2)，53 (1987).

29) T. Kobayashi, M. Haruta, H. Sano and M. Nakane: Sens. Actuators 8 (1987). 